https://jurnal.uns.ac.id/jdc

\title{
Analisis Kesalahan Siswa pada Tes Kemampuan Dasar Matematika Kelas III Sekolah Dasar
}

\author{
Wahyudi \\ Universitas Sebelas Maret \\ wahyudi@fkip.uns.ac.id
}

\section{Sejarah Artikel}

diterima 13/08/2019

\begin{abstract}
The research aims to describe: (1) the types of students' errors, (2) the causes of students' mistakes, (3) how to fix the students' mistakes. It is qualitative research. The research subjects are all students and teachers of third grade in the group of Banyumudal Elementary School, Kebumen Subdistrict, in academic year 2018/2019. The results shows that (1) the types of students' errors are: (a) writing, reading names and numbers symbol (b) sorting numbers, (c) place values, (d) subtracting numbers, (e) multiplying 2 numbers, (f) dividing numbers, (g) mixed count operations, (h) comparing, adding, subtracting fractions with equal denominators, (i) calculating money values, (j) square, rectangular, angular, (k) measuring length, area, weight and time; while (2) the cause of students' mistakes is the lack of understanding in concepts and materials; and (3) how to fix the students' mistakes is through learning improvement with a focus in the types and causes of student errors.
\end{abstract}

Keywords: error analysis, basic ability test, mathematics

\begin{abstract}
Abstrak
Tujuan penelitian ini adalah: (1) mendeskripsikan jenis kesalahan siswa, (2) mendeskripsikan sebab kesalahan siswa, (3) mendeskripsikan cara memperbaiki kesalahan siswa. Penelitian ini yaitu Penelitian Kualitatif dengan subjek adalah siswa dan guru kelas III Sekolah Dasar Gugus Banyumudal Kecamatan Kebumen Tahun ajaran 2018/2019. Hasil yang penelitian ini adalah: (1) jenis kesalahan siswa adalah: (a) menulis, membaca nama dan lambang bilangan (b) mengurutkan bilangan, (c) nilai tempat, (d) mengurang bilangan, (e) mengalikan 2 bilangan, (f) membagi bilangan, (g) operasi hitung campuran, (h) membandingkan, menjumlahkan, mengurangkan pecahan dengan penyebut sama., (i) perhitungan nilai uang, (j) persegi, persegi panjang, sudut, (k) pengukuran panjang, luas, berat, dan waktu; (2) penyebab kesalahan siswa adalah kurang memahami konsep dan materi; (3) cara memperbaiki kesalahan siswa adalah melalui pembelajaran perbaikan dengan fokus pada jenis dan penyebab kesalahan siswa.

Kata kunci: analisis kesalahan, tes kemampuan dasar, matematika
\end{abstract}




\section{PENDAHULUAN}

Pendidikan nasional berfungsi mengembangkan kemampuan dan membentuk watak serta peradaban bangsa yang bermartabat dalam rangka mencerdaskan kehidupan bangsa, bertujuan untuk berkembangnya potensi agar menjadi manusia beriman dan bertakwa kepada Tuhan Yang Maha Esa, berakhlak mulia, sehat, berilmu, cakap, kreatif, mandiri, dan menjadi warga negara yang demokratis serta bertanggung jawab. ( UU No.20 Tahun 2003: 6).

Sekolah Dasar merupakan salah satu lembaga pendidikan yang mengupayakan untuk mewujudkan tujuan nasional tersebut. Dalam kegiatan pembelajaran di sekolah, setiap siswa tidak mungkin terhindar dari kegiatan penilaian hasil belajar. Kegiatan penilaian hasil belajar dilaksanakan secara sistematis dan berkelanjutan. "Penilaian adalah kegiatan untuk mengetahui perkembangan, kemajuan, dan/ atau hasil belajar siswa selama Program Pendidikan". Salah satu kegiatan penilaian yang dilaksanakan di Sekolah Dasar yaitu Tes Kemampuan Dasar (TKD). Pelaksanaan Tes Kemampuan Dasar ini berdasarkan Keputusan Menteri Pendidikan Nasional Republik Indonesia Nomor: 012/U/2002 tentang Sistem Penilaian di Sekolah Dasar, Sekolah Dasar Luar Biasa, Sekolah Dasar Luar Biasa Tingkat Dasar, dan Madrasah Ibtidaiyah, disebutkan pada pasal 3 (2) yang berbunyi "Selain jenis penilaian sebagaimana dimaksud pada ayat (1) dapat dilakukan Tes Kemampuan Dasar dan Penilaian
Mutu Pendidikan" (Ditjen Dikdasmen, 2002: 32-33).

Tes Kemampuan Dasar ini diberikan kepada siswa kelas 3 Sekolah Dasar yang dilaksanakan sekali dalam setahun, tepatnya pada akhir tahun ajaran. Ada tiga kemampuan dasar yang harus dikuasai oleh seluruh siswa yaitu kemampuan membaca, menulis dan berhitung (calistung). Ketiga kemampuan itu merupakan dasar untuk mempelajari mata pelajaran yang lain dan digunakan dalam kehidupan sehari-hari sehingga dapat beradaptasi dengan masyarakat. Berhitung merupakan salah satu kajian inti matematika di sekolah dasar .Berdasarkan kenyataan yang ada di diketahui bahwa prestasi siswa dalam berhitung masih sangat rendah. Nilai rata-rata mata pelajaran matematika dalam Ulangan Umum Semester 1 belum mencapai KKM (Kriteria Ketuntasan Minimal).

Tes Kemampuan Dasar yang dilaksanakan di Sekolah Dasar bertujuan untuk mengetahui kemampuan siswa tentang membaca, menulis dan berhitung, yang diperlukan dalam rangka memperbaiki program pembelajaran atau remedial, di tingkat sekolah, tingkat nasional, bahkan tingkat internasional. Setelah tes tersebut dikerjakan siswa maka perlu diadakannya tindak lanjut yang diantaranya dengan melakukan analisis terhadap butir-butir soal Tes Kemampuan Dasar dan diagnosis kesalahan terhadap hasil pekerjaan siswa. Dengan analisis butir soal dapat diketahui apakah soal tes tersebut sudah memenuhi kriteria tes yang baik, tinggi rendahnya prestasi 
belajar siswa. Diagnosis kesalahan dapat kita tentukan jenis-jenis kesalahan yang dilakukan siswa, penyebab kesalahan dan juga dapat diketahui cara yang harus dilakukan untuk memperbaiki kesalahan yang dilakukan siswa (Depdiknas, 2007). Cara untuk memperbaiki kesalahan atau kesulitan siswa dalam pembelajaran dapat dilakukan melalui pembelajaran perbaikan (remedial teaching) (Depdiknas, 2008).

Tes Kemampuan Dasar (TKD) yang dilaksanakan mempunyai fungsi sebagai: (1) alat penjamin pengawasan dan pengendalian mutu pendidikan, (2) umpan balik dalam perbaikan program pembelajaran pada sekolah, (3) alat pendorong dalam meningkatkan kemampuan siswa khususnya kemampuan membaca, menulis dan berhitung. Adapun manfaat dilaksanakannya Tes Kemampuan Dasar (TKD) adalah untuk: (1) memberikan informasi sekaligus peringatan dini (early warning system) kepada semua pihak tentang tingkat kemampuan siswa dalam hal membaca, menulis dan berhitung; (2) mendiagnosis kelemahan siswa dalam membaca, menulis dan berhitung; (3) umpan balik bagi guru dalam memperbaiki pembelajaran; (4) pemetaan mutu sekolah (school mapping) yang didasarkan pada kemampuan siswa dalam membaca, menulis dan berhitung; (5) bahan pertimbangan dalam pengambilan kebijakan pendidikan, khususnya yang menyangkut pembinaan kemampuan membaca, menulis, dan berhitung (Depdiknas, 2002: 3 - 4).

Ashlock (1998) menyimpulkan bahwa guru harus memahami siswa mereka belajar dan harus mengidentifikasi kesenjangan dan kesalahpahaman dalam pembelajaran matematika mereka. Analisis kesalahan matematika memerlukan pengetahuan pedagogis para guru untuk menganalisis dan menafsirkan kesalahan. Ini membantu guru untuk memperluas kognisi matematika siswa dan untuk meningkatkan pembelajaran.

Analisis kesalahan atau analisis pola kesalahan adalah analisis kesalahan pada pekerjaan matematika siswa dengan tujuan mengidentifikasi pola umum dan untuk menemukan penjelasan tentang penyebab kesalahan ini (Herholdt dan Sapire, 2014). Analisis kesalahan memungkinkan guru menerapkan remediasi yang efektif (McGuire, 2013) dan merupakan alat diagnostik yang efektif untuk menjembatani kesenjangan antara hasil yang diharapkan dan kinerja.

Tidak semua jenis kesalahan siswa dapat dikaitkan dengan pengetahuan konseptual dan prosedural. Kesalahan yang timbul karena faktor lain selain kurangnya pengetahuan dan keterampilan disebut sebagai kesalahan "ceroboh" (Yang, 2011) atau "Tergelincir" menurut Oliver (1996). Ini disebut sebagai kesalahan non-sistematis yang tidak disebabkan karena pengetahuan konseptual atau prosedural. Yetkin (2003) melaporkan bahwa sebagian besar kesalahan yang dilakukan siswa adalah kesalahan sistematis dan berbasis aturan daripada kesalahan nonsistematis. Analisis kesalahan berfokus pada kesalahan sistematis yang terjadi secara konsisten dan lazim pada pekerjaan siswa yang mencerminkan kurangnya pengetahuan dan keterampilan. Identifikasi kesalahan sangat penting bagi siswa yang memiliki ketidakmampuan belajar dan siswa 
yang berprestasi rendah (Fuchs, Fuchs, \& Hamlett, 1994; Salvia \& Ysseldyke, 2004). Dengan menunjukkan kesalahan siswa, guru dapat memberikan pembelajaran sesuai dengan kebutuhan siswa. Secara umum, siswa yang mengalami kesulitan belajar matematika biasanya kurang memiliki pengetahuan konseptual yang memadai karena beberapa alasan, termasuk ketidakmampuan memproses informasi dengan kecepatan pembelajaran, kurang memadai kesempatan untuk menjawab soal, kurangnya umpan balik dari guru tentang kesalahan atau kesulitan belajar, kecemasan tentang matematika, dan kesulitan dalam pemrosesan visual dan/atau pendengaran (University of Kansas). Langkah pertama analisis kesalahan adalah mengidentifikasi dengan benar kesalahan spesifik yang ditampilkan dalam pekerjaan siswa. Kurangnya pengetahuan siswa dapat menjadi alasan utama mengapa mereka tidak dapat menyelesaikan masalah tertentu secara konsisten (Hudson \& Miller, 2006). Analisis kesalahan adalah metode yang biasa digunakan untuk mengidentifikasi penyebab kesalahan siswa ketika mereka membuat kesalahan secara konsisten. Ini adalah proses meninjau pekerjaan siswa dan kemudian mencari pola kesalahpahaman. Kesalahan dalam matematika bisa berupa kesalahan faktual, prosedural, atau konseptual, dan dapat terjadi karena beberapa alasan (Lai, 2012: 1).

Ada tiga jenis kesalahan, yaitu kesalahan prosedural, faktual, dan konseptual. Ketika seorang siswa belum mengikuti langkah (atau prosedur) yang benar untuk Memecahkan masalah, ini adalah kesalahan prosedural. Kesalahan faktual adalah kesalahan yang dilakukan siswa ketika mereka tidak dapat mengingat fakta yang diperlukan untuk memecahkan masalah atau jika mereka belum menguasainya fakta dasar. Kesalahan konseptual terlihat seperti kesalahan prosedural, tetapi itu terjadi karena siswa tidak sepenuhnya memahami konsep matematika tertentu, seperti nilai tempat (Ginsburg, 1987, sebagaimana dikutip di di University of Kansas, n.d.). Dengan demikian, kesalahan konseptual adalah kesalahan yang lebih serius. Untuk menentukan apakah ada kesalahan konseptual, guru harus memeriksa dengan meminta siswa untuk menjelaskan masalah dengan benda konkret atau menunjukkan dan menjelaskan langkah-langkah yang digunakan untuk menyelesaikan masalah (Hudson \& Miller, 2006).

Pembelajaran perbaikan (Remedial teaching) adalah suatu bentuk pembelajaran yang bersifat menyembuhkan atau membetulkan sehingga menjadi lebih baik (Ahmadi dan Supriyono, 1990: 145). Selanjutnya, Good (dalam Sukardi, 2010: 228) menyatakan bahwa "class remedial is a specially selected group of pupils in need of more intensive instruction in some area education than is possible in the reguler classroom". Abdurrahman (dalam Hastuti, 2000: 1) menyatakan bahwa "remedial teaching pada hakikatnya merupakan kewajiban bagi semua guru setelah mereka melakukan evaluasi formatif dan menemukan adanya peserta didik yang belum mencapai tujuan belajar yang telah ditetapkan". Pembelajaran remedial menurut Abror (1993: 185) adalah bentuk pembelajaran perbaikan yang diberikan kepada seseorang siswa untuk membantu memecahkan 
kesulitan belajar yang dihadapinya. Syamsuddin (2005: 343) pembelajaran remedial adalah sebagai upaya guru untuk menciptakan suatu situasi yang memungkinkan individu atau kelompok siswa dengan kerakter tertentu lebih mampu meningkatkan prestasi belajar seoptimal mungkin sehingga dapat memenuhi kriteria keberhasilan minimal yang diharapkan. Berdasarkan beberapa pendapat tersebut, dapat disimpulkan bahwa bahwa pembelajaran perbaikan (remedial teaching) adalah suatu bentuk pembelajaran khusus, yang bertujuan untuk menyembuhkan atau memperbaiki sebagian atau seluruh kesulitan belajar yang dihadapi oleh peserta didik. Program remedial diharapkan dapat membantu peserta didik yang belum tuntas untuk mencapai ketuntasan hasil belajar sesuai dengan tujuan pembelajaran.

Berdasarkan hasil pengamatan di lapangan yang dilaksanakan pada bulan Februari 2019 pada 5 sekolah dasar di Gugus Banyumudal Kecamatan Kebumen- Kabupaten Kebumen menunjukkan bahwa hasil Tes, Kemampuan Dasar Matematika rata-rata hanya 48,03 . Dari hasil tes masing-masing sekolah tersebut langsung dikirim ke tingkat kecamatan dalam bentuk laporan, tanpa adanya tindak lanjut baik dari guru maupun dari instansi terkait. Kegiatan analisis kesalahan dari hasil Tes Kemampuan Dasar dan tindak lanjutnya belum pernah dilakukan, sehingga dampak dari kegiatan Tes Kemampuan Dasar (TKD) baik yang berhubungan dengan kemampuan penguasaan materi maupun peningkatan pembelajaran yang berkaitan kemampuan dasar ini belum dapat dirasakan di lapangan. Berdasarkan kenyataan tersebut, peneliti terpanggil untuk melaksanakan penelitian yang berkaitan dengan Tes Kemampuan Dasar. Tujuan penelitian ini adalah: (1) mendeskripsikan jenis kesalahan siswa kelas III Sekolah Dasar pada Tes Kemampuan Dasar (TKD) Matematika, (2) mendeskripsikan penyebab kesalahan siswa kelas III Sekolah Dasar pada Tes Kemampuan Dasar (TKD) Matematika. mendeskripsikan cara memperbaiki kesalahan siswa Kelas III Sekolah Dasar pada Tes Kemampuan Dasar (TKD) Matematika.

\section{METODE}

Bentuk atau pendekatan dalam penelitian ini yaitu Penelitian Kualitatif dan Penelitian Tindakan Kelas (PTK). Strategi penelitian ini mengacu pada penelitian deskriptif yaitu dengan menyimpulkan data sebanyakbanyaknya mengenai jenis-jenis dan penyebab kesalahan pada Tes Kemampuan Dasar Matematika. Berdasarkan jenis dan penyebab kesalahan tersebut, kemudian dilakukan tindakan atau cara untuk memperbaiki kesalahan yang dilakukan siswa dengan menggunakan PTK. Dengan demikian Pelaksanaan Penelitian Tindakan Kelas ini digunakan untuk memperbaiki kesalahan-kesalahan siswa dalam menyelesaikan soal Tes Kemampuan Dasar Matematika.

Subjek penelitian ini adalah 170 siswa dan 7 guru kelas III pada 5 Sekolah Dasar yang berada di Gugus Banyumudal Kecamatan Kebumen Kabupaten Kebumen Tahun ajaran 2018/2019. Sumber data yang digunakan dalam penelitian ini adalah 
siswa dan guru kelas III Sekolah Dasar. Adapun teknik pengumpulan data yang digunakan pada penelitian ini adalah tes, wawancara, observasi lapangan.

Instrumen yang digunakan pada penelitian ini adalah Tes Kemampuan Dasar (TKD)
Matematika, yang meliputi ruang lingkup materi: (1) bilangan, (2) mata uang, (3) geometri, dan (4) pengukuran. Tes Kemampuan Dasar Matematika dilakukan secara tertulis dalam waktu 120 menit. Adapun kisikisi soal Tes Kemampuan Dasar Matematika disajikan sebagai berikut.

Tabel 1: Kisi-kisi Tes Kemampuan Dasar Matematika

\begin{tabular}{|c|c|c|c|c|}
\hline \multirow{2}{*}{$\begin{array}{c}\text { Kompetensi } \\
\text { yang Diujikan }\end{array}$} & \multirow{2}{*}{$\begin{array}{c}\text { Jumlah } \\
\text { Indikator }\end{array}$} & \multicolumn{3}{|c|}{ Bentuk Soal \& Nomor Soal } \\
\hline & & Pilihan Ganda & Isian & Uraian \\
\hline Bilangan & 28 & $\begin{array}{l}1,2,3,4,5,6,7 \\
8,9,10,11,12 \\
13,14,15,16\end{array}$ & $\begin{array}{l}21,22,23,24, \\
25,26,27,28, \\
29,30,31\end{array}$ & 41, \\
\hline Mata Uang & 3 & 20 , & 35,40 & \\
\hline Geometri & 4 & 19 & 34,39 & 44 \\
\hline Pengukuran & 9 & 17, 18, & $\begin{array}{l}32,33,36,37 \\
38,\end{array}$ & 42,43 \\
\hline Jumlah & 44 & 20 & 20 & 4 \\
\hline
\end{tabular}

Untuk mengetahui pada jenjang mana seorang siswa memperoleh nilai Tes Kemampuan Dasarnya, maka dirujukkan pada ketentuan kriteria atau patokan nilai (predikat prestasi) sebagai berikut: skor > 95 (Istimewa), skor 80 - 94,9 (Amat baik), skor 65 79,9 (Baik), skor 50 - 64,9 (Cukup), skor 35 - 49,9 (Kurang), dan skor < 3,50 (Amat kurang). Instrumen tes yang digunakan pada penelitian ini sepenuhnya menggunakan instrumen tes yang disusun oleh Depdiknas (2002: 62 - 75).

Validitas data dalam penelitian ini diperoleh melalui triangulasi, yaitu triangulasi sumber dan triangulasi teknik. Analisis data yang digunakan adalah analisis kualitatif yang meliputi tiga alur kegiatan yang terjadi secara bersama-sama dan terus-menerus selama dan setelah pengumpulan data, yaitu reduksi data, penyajian data dan penarikan kesimpulan atau verifikasi (Miles \& Huberman, 1992).

\section{PEMBAHASAN}

\section{Kesalahan Penyebabnya Matematika Kelas III Dasar \\ Siswa dan pada TKD \\ Sekolah}

\section{A. Bilangan}

Soal:

Perhatikan gambar di bawah ini

(n)


Kunci Jawaban: 2764

Jawaban Siswa:

Dari 170 siswa yang menjawab benar sebanyak 85 siswa (50\%), sedangkan 85 siswa (50\%) menjawab salah. Dari jawaban siswa yang salah, sebagian besar menjawab 7.426. Itu artinya siswa langsung menuliskan banyaknya benda yang terdapat pada nilai tempat secara berurutan seperti pada gambar, tanpa memperhatikan makna nilai tempat yaitu urutan dari kanan ke kiri adalah satuan, puluhan, ratusan, dan ribuan. Penyebab kesalahan ini adalah (a) siswa kurang memahami makna nilai tempat, (b) siswa kurang teliti dalam memperhatikan urutan nilai tempat.

Soal:

Diketahui urutan bilangan 1.104 1.109 , 1.114

Lanjutan dari urutan bilangan tersebut adalah

Kunci Jawaban: 1119

Jawaban Siswa:

Dari 170 siswa yang menjawab benar sebanyak 73 siswa (43\%), sedangkan 97 siswa (57\%) menjawab salah. Dari jawaban siswa yang salah, sebagian besar menjawab 1019 dan sebagian lagi menjawab 1115. Itu artinya siswa kurang memahami urutan dan pola bilangan. Penyebab kesalahan ini adalah (a) siswa kurang memahami urutan bilangan, (b) siswa kurang memahami pola bilangan.

Soal:

Diketahui bilangan 9.817

Pada bilangan di atas, angka yang menempati tempat puluhan adalah

Kunci Jawaban: 1

Jawaban Siswa:
Dari 170 siswa yang menjawab benar sebanyak 126 siswa (74\%), sedangkan 44 siswa (26\%) menjawab salah. Dari jawaban siswa yang salah, sebagian besar menjawab 8 dan sebagian lagi menjawab 9. Itu artinya siswa kurang memahami nilai tempat. Penyebab kesalahan ini adalah (a) siswa kurang memahami nilai tempat, (b) siswa kurang teliti dalam menjawab.

Soal:

6.083

3.272

Kunci Jawaban: 2811

Jawaban Siswa:

Dari 170 siswa yang menjawab benar sebanyak 42 siswa (25\%), sedangkan 128 siswa (75\%) menjawab salah. Dari jawaban siswa yang salah, sebagian besar menjawab 3011 dan sebagian lagi 9355. Itu artinya siswa kurang memahami pengurangan bentuk bersusun dengan teknik meminjam. Penyebab kesalahan ini adalah (a) siswa kurang memahami konsep pengurangan, (b) siswa mengerjakan bilangan besar dikurangi bilangan kecil, (c) siswa mengerjakan penjumlahan pada soal pengurangan, (d) siswa kurang teliti pada saat mengerjakan.

Soal:

$9.412-4.323-698=\ldots \ldots \ldots \ldots \ldots \ldots$

Kunci Jawaban: 4391

Jawaban Siswa:

Dari 170 siswa yang menjawab benar sebanyak 4 siswa (2\%), sedangkan 164 siswa (98\%) menjawab salah. Dari jawaban siswa yang salah, sebagian besar menjawab 3491 dan sebagian lagi 5587. Itu artinya siswa 
kurang memahami pengurangan bentuk bersusun tiga bilangan dengan teknik meminjam. Penyebab kesalahan ini adalah (a) siswa kurang memahami konsep pengurangan, (b) siswa kurang memahami pengurangan tiga bilangan, (c) siswa kurang teliti pada saat mengerjakan.

Soal:

Ibu membeli 7 ikat rambutan. Setiap ikat berisi 15 butir.

Maka jumlah rambutan seluruhnya butir.

Kunci Jawaban: 105

Jawaban Siswa:

Dari 170 siswa yang menjawab benar sebanyak 88 siswa (52\%), sedangkan 82 siswa (48\%) menjawab salah. Dari jawaban siswa yang salah, sebagian besar menjawab 22 dan sebagian lain lagi 95 dan 8 . Itu artinya siswa kurang memahami konsep perkalian sebagai penjumlahan berulang. Penyebab kesalahan ini adalah (a) siswa kurang memahami konsep perkalian, (b) siswa mengerjakan soal perkalian dengan penjumlahan, (c) Siswa kurang menguasai fakta dasar perkalian, (d) siswa mengerjakan soal perkalian dengan pengurangan (c) siswa kurang teliti membaca soal cerita.

Soal:

SD Makmur mempunyai 14 ruang kelas. Di setiap ruang kelas ada 36 buah kursi murid. Maka jumlah kursi murid semuanya ada buah.

Kunci Jawaban: 504

Jawaban Siswa:

Dari 170 siswa yang menjawab benar sebanyak 36 siswa (21\%), sedangkan 134 siswa (79\%) menjawab salah. Dari jawaban siswa yang salah, sebagian besar menjawab 50 dan sebagian lain lagi 410. Itu artinya siswa kurang memahami konsep perkalian sebagai penjumlahan berulang. Penyebab kesalahan ini adalah (a) siswa kurang memahami konsep perkalian, (b) siswa mengerjakan soal perkalian dengan penjumlahan, (c) siswa kurang memahami cara menentukan hasil perkalian dua bilangan dua angka, (d) Siswa kurang menguasai fakta dasar perkalian, (e) siswa kurang teliti membaca soal cerita.

Soal:

138: $6=n, \quad$ Nilai $n$ pada pembagian di atas adalah

Kunci Jawaban: 23

Jawaban Siswa:

Dari 170 siswa yang menjawab benar sebanyak 60 siswa (35\%), sedangkan 110 siswa (65\%) menjawab salah. Dari jawaban siswa yang salah, sebagian besar menjawab 32 dan sebagian lain lagi 23. Itu artinya siswa kurang memahami konsep pembagian bilangan tiga angka dengan satu angka. Penyebab kesalahan ini adalah (a) siswa kurang memahami konsep pembagian, (b) siswa kurang terampil menentukan pembagian bilangan tiga angka dengan atu angka, (c) siswa kurang teliti dalam menentukan hasil pembagian bilangan tiga angka dengan satu angka.

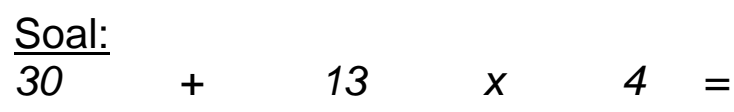

Kunci Jawaban: 82

Jawaban Siswa: 
Dari 170 siswa yang menjawab benar sebanyak 60 siswa (35\%), sedangkan 100 siswa (65\%) menjawab salah. Dari jawaban siswa yang salah, sebagian besar menjawab 172 dan sebagian lain lagi 84 . Itu artinya siswa kurang memahami algoritma pengerjaan hitung campuran. Penyebab kesalahan ini adalah (a) siswa mengerjakan secara urut tanpa memperhatikan algoritma operasi hitung campuran, (b) siswa kurang teliti dalam menentukan hasil perkalian, (c) siswa kurang teliti dalam menentukan hasil operasi hitung campuran.

Soal:

$2.938+90 \times 12-1.609=$

Kunci Jawaban: 2409

Jawaban Siswa:

Dari 170 siswa yang menjawab benar sebanyak 9 siswa (5\%), sedangkan 161 siswa (95\%) menjawab salah. Dari jawaban siswa yang salah, sebagian besar menjawab 2603 dan sebagian lain lagi 1427 . Itu artinya siswa kurang memahami algoritma pengerjaan hitung campuran. Penyebab kesalahan ini adalah (a) siswa mengerjakan secara urut tanpa memperhatikan algoritma operasi hitung campuran, (b) siswa kurang teliti dalam menentukan hasil perkalian, (c) siswa kurang teliti dalam menentukan hasil operasi hitung campuran.

Soal:

$16 \times 14: 7=n$, maka nilai $n$ adalah

Kunci Jawaban: 32

Jawaban Siswa:

Dari 170 siswa yang menjawab benar sebanyak 46 siswa (27\%), sedangkan
124 siswa (73\%) menjawab salah. Dari jawaban siswa yang salah, sebagian besar menjawab 3 dan sebagian lain lagi 30 . Itu artinya siswa kurang memahami algoritma pengerjaan hitung campuran. Penyebab kesalahan ini adalah (a) siswa kurang teliti dalam menentukan hasil pembagian, (b) siswa mengerjakan dengan mengalikan semua bilangan, (c) siswa kurang teliti dalam menentukan hasil operasi hitung campuran.

Soal:

$(8.637-8.349): 9 \times 6+2.488=$

Kunci Jawaban: 2680

Jawaban Siswa:

Dari 170 siswa yang menjawab benar sebanyak 4 siswa (2\%), sedangkan 166 siswa (98\%) menjawab salah. Dari jawaban siswa yang salah, sebagian besar menjawab 3034 dan sebagian lain lagi tidak menjawab. Itu artinya siswa kurang memahami algoritma pengerjaan hitung campuran. Penyebab kesalahan ini adalah (a) siswa kurang memahami algoritma hitung campuran, (b) siswa kurang teliti dalam menentukan hasil operasi hitung.

Soal:

Diketahuigambar sebagai berikut:

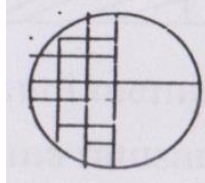

A

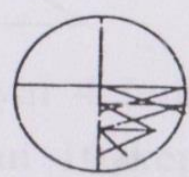

B
Hasil penjumlahan pecahan dari daerah berbayang-bayang $A$ dengan daerah berbayang-bayang $B$ adalah 
Kunci Jawaban: 3/4

Jawaban Siswa:

Dari 170 siswa yang menjawab benar sebanyak 8 siswa (5\%), sedangkan 162 siswa (95\%) menjawab salah. Dari jawaban siswa yang salah, sebagian besar menjawab 2/4 dan $1 / 4$, serta dan sebagian lain lagi menjawab $A$. Itu artinya siswa kurang memahami konsep penjumlahan pecahan. Penyebab kesalahan ini adalah (a) siswa kurang memahami konsep penjumlahan pecahan, (b) siswa kurang memahami konsep pecahan yang ditunjukkan dengan luasan daerah.

\section{B. Mata Uang}

Soal:

Uang saku Dodi setiap hari $R p$ 2.000,00. Dari uang tersebut ditabung Rp 250,00

Setelah 30 hari tabungan Dodi menjadi

Kunci Jawaban: Rp 7.500,00

Jawaban Siswa:

Dari 170 siswa yang menjawab benar sebanyak 66 siswa (39\%), sedangkan 104 siswa (61\%) menjawab salah. Dari jawaban siswa yang salah, sebagian besar menjawab $R p$ $2.500,00$ dan $R p$ 750,00, serta dan sebagian lain lagi menjawab $R p$ $5.000,00$. Itu artinya siswa kurang memahami besar tabungan dan waktu menabung. Penyebab kesalahan ini adalah siswa kurang memperhatikan jangka waktu menabung, (b) siswa kurang teliti dalam mengalikan tabungan dengan waktu menabung, (c) siswa kurang teliti dalam memahami isi soal cerita.

Soal:

Deni membeli 4 buah buku tulis seharga Rp 4.800,00, 2 buah bolpoin seharga Rp 1.850,00 dan sebuah penggaris seharga $R p$ 1.250,00. Deni membayar dengan 2 lembar uang lima ribuan. Maka uang kembalian Deni rupiah.

Kunci Jawaban: 2.100

Jawaban Siswa:

Dari 170 siswa yang menjawab benar sebanyak 14 siswa (8\%), sedangkan 156 siswa (92\%) menjawab salah. Dari jawaban siswa yang salah, sebagian besar menjawab $R p$ $4.000,00$ dan sebagian lain lagi menjawab $\mathrm{Rp} 6.900,00$. Itu artinya siswa kurang memahami makna soal cerita. Penyebab kesalahan ini adalah (a) siswa kurang memahami isi doal cerita, (b) siswa kurang teliti dalam menghitung jumlah pembayaran, dan (c) siswa kurang teliti dalam mengitung sisa uang pengembalian belanja.

Soal:

Andi mempunyai 4 lembar uang ribuan, 7 keping lima ratusan dan 16 keping ratusan. Jumlah uang Andi seluruhnya adalah rupiah.

Kunci Jawaban: 9.100

Jawaban Siswa:

Dari 170 siswa yang menjawab benar sebanyak 25 siswa (15\%), sedangkan 145 siswa (85\%) menjawab salah. Dari jawaban siswa yang salah, sebagian besar menjawab 27 dan 4.716 dan sebagian lain lagi menjawab 9.200. Itu artinya siswa kurang memahami makna soal cerita. Penyebab kesalahan ini adalah (a) siswa kurang memahami isi doal cerita, (b) siswa kurang teliti dalam menghitung jumlah setiap nominal uang, dan (c) siswa kurang teliti dalam mengitung jumlah uang seluruhnya. 


\section{Geometri}

Soal:

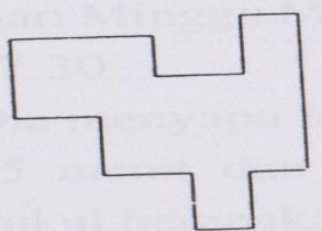

Gambar di atas ini mempunyai buah Sudut siku-siku.

Kunci Jawaban: 14

Jawaban Siswa:

Dari 170 siswa yang menjawab benar sebanyak 32 siswa (19\%), sedangkan 138 siswa (81\%) menjawab salah. Dari jawaban siswa yang salah, sebagian besar menjawab 9 dan sebagian lain lagi menjawab 3 dan 13. Itu artinya siswa kurang memahami Konsep sudut. Penyebab kesalahan ini adalah (a) siswa kurang memahami konsep sudut, (b) siswa kurang teliti dalam mengitung banyaknya sudut siku-siku.

\section{Pengukuran}

Soal:

Perhatikan gambar di bawah ini !

\begin{tabular}{|l|l|l|}
\hline merah & kuning & biru \\
\hline
\end{tabular}

$18 \mathrm{dm}$

$$
1,5 \mathrm{~m}
$$

$\mathrm{cm}$.

Paman membeli kayu 4 meter. Kayu ini dicat warna merah 1,5 meter, dicat warna kuning 18 desimeter dan sisanya dicat warna biru.

Berapa centi meter kah kayu yang dicat warna biru?

Kunci jawaban: $70 \mathrm{Cm}$
Jawaban Siswa:

Dari 170 siswa, tidak ada yang menjawab benar $(0 \%)$, sedangkan 170 siswa (100\%) menjawab salah. Dari jawaban siswa yang salah, sebagian besar menjawab $400 \mathrm{Cm}$, dan sebagian yang lain menjawab 20 dan $3 \mathrm{~cm}$. Itu artinya siswa kurang memahami Konsep satuan panjang. Penyebab kesalahan ini adalah (a) siswa kurang memahami konsep satuan panjang, (b) siswa kurang memahami tentang konversi satuan panjang, (c) siswa kurang teliti dalam menjawab pertanyaan, (c) siswa kurang memahami maksud pertanyaan.

Soal:

Panjang pita Nani $42 \mathrm{~cm}$. Panjang pita Rina $340 \mathrm{~mm}$.

Maka pernyataan yang benar adalah

...

Kunci jawaban: Pita Nani lebih panjang dari pita Rina Jawaban Siswa:

Dari 170 siswa, yang menjawab benar sebanyak 25 siswa (18\%), sedangkan 145 siswa (82\%) menjawab salah. Dari jawaban siswa yang salah, sebagian besar menjawab Pita Nani lebih pendek dari pita Rina, dan sebagian yang lain menjawab Pita Rina lebih panjang dari pita Nani. Itu artinya siswa kurang memahami Konsep satuan panjang. Penyebab kesalahan ini adalah (a) siswa kurang memahami konsep satuan panjang, (b) siswa kurang memahami tentang konversi satuan panjang, (c) siswa kurang teliti dalam menjawab pertanyaan, (c) siswa kurang memahami tentang membendingkan satuan panjang. 
Soal:

Ibu membeli 4/6 kilogram tepung. Karena kurang, ibu membeli lagi 2/6 $\mathrm{kg}$.

Ibu memakai 5/6 kg. Tepung tersebut kue.

Sisa tepung terigu ibu tinggal kilo gram. untuk membuat

Kunci jawaban: 1/6

Jawaban Siswa:

Dari 170 siswa, yang menjawab benar sebanyak 71 (42\%), sedangkan 99 siswa $(58 \%)$ menjawab salah. Dari jawaban siswa yang salah, sebagian besar menjawab 3, dan sebagian yang lain menjawab 5/6. Itu artinya siswa kurang memahami Konsep satuan berat. Penyebab kesalahan ini adalah (a) siswa kurang memahami konsep satuan berat, (b) siswa kurang memahami konsep pecahan, (c) siswa kurang teliti dalam menghitung satuan berat.

Soal:

Berat badan Arman $28 \mathrm{~kg}$. Berat badan Yuni 15 ons lebih ringan dari berat badan Arman. Jadi berat badan Yuni kilogram.

Kunci jawaban: 26,5

Jawaban Siswa:

Dari 170 siswa, tidak ada yang menjawab benar (0\%), sedangkan 170 siswa (100\%) menjawab salah. Dari jawaban siswa yang salah, sebagian besar menjawab 15, dan sebagian yang lain menjawab 150. Itu artinya siswa kurang memahami Konsep satuan berat. Penyebab kesalahan ini adalah (a) siswa kurang memahami konsep satuan berat, (b) siswa kurang memahami konversi satuan berat, (c) siswa kurang memahami soal cerita dan maksud pertanyaan.
Soal:

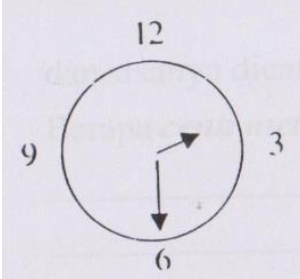

Gambar jam di atas menunjukkan waktu Rizky mulai kursus bahasa Inggris.

Dia kursus selama 2 jam. Jadi Rizky pulang kursus pukul

Kunci jawaban: 16.30

Jawaban Siswa:

Dari 170 siswa, yang menjawab benar sebanyak 16 (9\%), sedangkan 154 siswa (91\%) menjawab salah. Dari jawaban siswa yang salah, sebagian besar menjawab 04.30, dan sebagian yang lain menjawab 2.30. Itu artinya siswa kurang memahami Konsep waktu. Penyebab kesalahan ini adalah (a) siswa kurang memahami pengukuran waktu, (b) siswa kurang memahami oprasi hitung satuan waktu, (c) siswa kurang teliti dalam memahami soal cerita dan maksud pertanyaan.

Soal:

Dhani pulang dari sekolah pukul 13.10. Dia sampai di rumah pukul 14.20

Lamanya perjalanan Dhani dari sekolah ke rumah menit

Kunci jawaban: 70

Jawaban Siswa:

Dari 170 siswa, yang menjawab benar sebanyak 30 (18\%), sedangkan 140 siswa (82\%) menjawab salah. Dari jawaban siswa yang salah, sebagian besar menjawab 60, dan sebagian yang lain menjawab 40 dan 50 . Itu artinya siswa kurang memahami Konsep waktu. Penyebab kesalahan ini adalah (a) siswa kurang memahami 
pengukuran waktu, (b) siswa kurang teliti dalam mengerjakan operasi hitung yang melibatkan satuan waktu.

Soal:

Kakak pulang dari seolah pukul 14.15. Ayah pulang dari kantor pukul 15.30. Selisih waktu pulang kakak dan ayah adalah menit.

Kunci jawaban: 75

Jawaban Siswa:

Dari 170 siswa, yang menjawab benar sebanyak 16 siswa (9\%), sedangkan 154 siswa (91\%) menjawab salah. Dari jawaban siswa yang salah, sebagian besar menjawab 60 , dan sebagian yang lain menjawab 30 . Itu artinya siswa kurang memahami Konsep waktu. Penyebab kesalahan ini adalah (a) siswa kurang memahami pengukuran waktu, (b) siswa kurang teliti dalam mengerjakan operasi hitung yang melibatkan satuan waktu.

Soal:

Hari Minggu Mila membersihkan rumah mulai pukul 07.30.
Dia menyapu lantai selama 25 menit, mengepel 45 menit dan mengelap kaca selama 20 menit. Pukul berapakah Mila selesai bekerja?

Kunci jawaban: Mila selesai bekerja pukul 09.00

Jawaban Siswa:

Dari 170 siswa, yang menjawab benar sebanyak 10 siswa (6\%), sedangkan 160 siswa (94\%) menjawab salah. Dari jawaban siswa yang salah, sebagian besar menjawab 08.30, dan sebagian yang lain menjawab 08.20. Itu artinya siswa kurang memahami Konsep waktu. Penyebab kesalahan ini adalah (a) siswa kurang memahami pengukuran waktu, (b) siswa kurang teliti dalam mengerjakan operasi hitung tentang waktu, (c) siswa kurang teliti dalam mengerjakan operasi hitung yang melibatkan satuan waktu.

Berdasarkan hasil analisis kesalahan siswa kelas III sekolah dasar di atas, maka dapat disimpulkan tentang jenis dan penyebab kesalahan siswa pada Tes Kemampuan Dasar Matematika sebagai berikut.

\section{Tabel 2: Jenis dan Penyebab kesalahan Siswa}

pada Tes Kemampuan Dasar Matematika

\begin{tabular}{|c|c|c|c|}
\hline No & $\begin{array}{c}\text { Materi dan } \\
\text { Kompetensi yang } \\
\text { Belum Tuntas }\end{array}$ & Jenis Kesalahan & Penyebab Kesalahan \\
\hline \multirow[t]{7}{*}{$\mathbf{A}$} & Bilangan & & \\
\hline & $\begin{array}{l}\text { Menulis lambang } \\
\text { bilangan sampai dengan } \\
10.000\end{array}$ & $\begin{array}{l}\text { Menulis, } \\
\text { membaca nama } \\
\text { dan Lambang }\end{array}$ & $\begin{array}{l}\text { Kurang memahami nama dan } \\
\text { lambang bilangan }\end{array}$ \\
\hline & Mengurutkan bilangan & $\begin{array}{l}\text { Mengurutkan } \\
\text { bilangan }\end{array}$ & $\begin{array}{l}\text { Kurang memahami urutan pada pola } \\
\text { bilangan }\end{array}$ \\
\hline & $\begin{array}{l}\text { Mengenal nilai tempat, } \\
\text { ribuan, ratusan, puluhan } \\
\text { dan satuan }\end{array}$ & Nilai tempat & $\begin{array}{l}\text { Kurang memahami nilai tempat } \\
\text { ribuan, ratusan, puluhan dan satuan }\end{array}$ \\
\hline & $\begin{array}{l}\text { Mengurang bilangan } \\
\text { paling besar } 10.000\end{array}$ & $\begin{array}{l}\text { Pengurangan } \\
\text { bilangan }\end{array}$ & $\begin{array}{l}\text { Kurang memahami operasi } \\
\text { pengurangan }\end{array}$ \\
\hline & $\begin{array}{l}\text { Mengalikan } 2 \text { bilangan } \\
1 \text { angka dengan } 2 \\
\text { angka serta bilangan } \\
\text { kelipatan sepuluh }\end{array}$ & Perkalian bilangan & Kurang memahami perkalian \\
\hline & $\begin{array}{l}\text { Membagi Bilangan } 3 \\
\text { angka dengan bilangan } \\
1 \text { angka }\end{array}$ & $\begin{array}{l}\text { Pembagian } \\
\text { bilangan }\end{array}$ & Kurang memahami pembagian \\
\hline
\end{tabular}




\begin{tabular}{|c|c|c|c|}
\hline No & $\begin{array}{c}\text { Materi dan } \\
\text { Kompetensi yang } \\
\text { Belum Tuntas }\end{array}$ & Jenis Kesalahan & Penyebab Kesalahan \\
\hline & $\begin{array}{l}\text { Mengerjakan hitung } \\
\text { campuran (berjumlah, } \\
\text { mengurang, mengali } \\
\text { dan membagi) bilangan } \\
\text { paling besar } 10.000\end{array}$ & $\begin{array}{l}\text { Operasi hitung } \\
\text { campuran }\end{array}$ & $\begin{array}{l}\text { Kurang memahami algoritma hitung } \\
\text { campuran }\end{array}$ \\
\hline & $\begin{array}{l}\text { Membandingkan, } \\
\text { menjumlahkan, } \\
\text { mengurangkan pecahan } \\
\text { dengan penyebut sama. }\end{array}$ & $\begin{array}{l}\text { Membandingkan } \\
\text { dan pengurangan } \\
\text { pecahan dengan } \\
\text { penyebut sama }\end{array}$ & Kurang memahami konsep pecahan \\
\hline \multirow[t]{2}{*}{ B } & Mata Uang & & \\
\hline & $\begin{array}{l}\text { Mengenal nilai uang dan } \\
\text { dapat memanfaatkan } \\
\text { dalam kehidupan sehari- } \\
\text { hari }\end{array}$ & $\begin{array}{l}\text { Operasi hitung } \\
\text { yang melibatkan } \\
\text { mata uang }\end{array}$ & $\begin{array}{l}\text { Kurang memahami konversi mata } \\
\text { uang }\end{array}$ \\
\hline \multirow[t]{2}{*}{$\mathbf{C}$} & Geometri & & \\
\hline & $\begin{array}{l}\text { Mengenal bangun datar } \\
\text { (persegi dan persegi } \\
\text { panjang, sudut siku-siku } \\
\text { dan bukan siku-siku) }\end{array}$ & $\begin{array}{l}\text { Konsep persegi, } \\
\text { persegi panjang, } \\
\text { sudut siku-siku }\end{array}$ & $\begin{array}{l}\text { Kurang memahami konsep luasan } \\
\text { daerah }\end{array}$ \\
\hline \multirow[t]{2}{*}{ D } & Pengukuran & & \\
\hline & $\begin{array}{l}\text { Membandingkan } \\
\text { panjang, luas, berat dan } \\
\text { menentukan waktu }\end{array}$ & $\begin{array}{l}\text { Pengukuran } \\
\text { panjang, luas, } \\
\text { berat, waktu }\end{array}$ & $\begin{array}{l}\text { Kurang memahami pengukuran } \\
\text { panjang, luas, dan waktu }\end{array}$ \\
\hline
\end{tabular}

Berdasarkan hasil analisis kesalahan di atas, maka dapat disimpulkan tentang jenis kesalahan siswa pada Tes Kemampuan Dasar Matematika kelas III sekolah dasar di Kabupaten Kebumen tahun 2019 adalah sebagai berikut: (1) menulis, membaca nama dan lambang bilangan (2) mengurutkan bilangan, (3) nilai tempat, (4) mengurang bilangan, (5) mengalikan 2 bilangan, (6) membagi bilangan, (7) operasi hitung campuran, membandingkan, menjumlahkan, mengurangkan pecahan dengan penyebut sama., (9) perhitungan nilai uang, (10) persegi, persegi panjang, sudut, (11) pengukuran panjang, luas, berat, dan waktu.

Adapun penyebab kesalahan tersebut adalah (1) kurang memahami nama dan lambang bilangan sampai dengan, (2) kurang memahami urutan pada pola bilangan, (3) kurang memahami nilai tempat ribuan, ratusan, puluhan dan satuan, (4) kurang memahami operasi pengurangan, (5) kurang memahami perkalian, (6) kurang memahami pembagian, (7) kurang memahami algoritma hitung campuran, (8) kurang memahami konsep pecahan, (9) kurang memahami konversi mata uang, (10) kurang memahami konsep luasan daerah, (11) kurang memahami pengukuran panjang, luas, dan waktu

\section{Cara memperbaiki kesalahan siswa Kelas III Sekolah Dasar pada Tes Kemampuan Dasar (TKD) Matematika.}

Berdasarkan jenis dan penyebab kesalahan siswa pada Tes Kemampuan Dasar Matematika kelas III sekolah dasar di Kabupaten Kebumen tahun 2019, maka untuk memperbaiki kesalahan tersebut 
dilakukan pembelajaran perbaikan dengan fokus pembelajarannya sesuai dengan ruang lingkup materi pelajaran, jenis dan penyebab kesalahannya. Kompetensi Tes Kemampuan Dasar Matematika yang perlu ditingkatkan adalah (1) bilangan dan operasi hitung bilangan, (2) opersi hitung uang, (3) pengukuran panjang, luas, dan waktu. Untuk itu, pembelajaran perbaikan dilaksanakan selama tiga kali pertemuan oleh guru kelas pada masing-masing sekolah dasar. Pembelajaran perbaikan tersebut dilaksanakan sesuai prosedur Penelitian Tindakan Kelas (PTK) dengan alur (1) perencanaan, (2) pelaksanaan, (3) observasi, dan (4) refleksi. Setelah pembelajaran perbaikan dilaksanakan, maka diakhiri dengan evaluasi berupa post-tes Kemampuan Dasar Matematika.
Berdasarkan hasil post-tes
menunjukkan bahwa terjadi peningkatan hasil belajar siswa terhadap materi Tes Kemampuan Dasar Matematika, dari skor rata-rata 48,03 pada pre-tes meningkat menjadi 63,75 pada rata-rata skor post-tes. Hal ini sesuai dengan tujuan pembelajaran perbaikan (remedial teaching), yaitu untuk (1) menyembuhkan atau membetulkan secara singkat pembelajaran sehingga menjadi lebih baik. (2) membantu memecahkan kesulitan belajar siswa, (3) meningkatkan prestasi siswa seoptimal mungkin sehingga dapat memenuhi kriteria keberhasilan minimal yang diharapkan (Ahmadi dan Supriyono, 1990: 145); (Sukardi, 2010: 228); Abror (1993: 185); (Syamsuddin, 2005: 43).

\section{SIMPULAN}

Berdasarkan hasil analisis dan pembahasan tentang hasil penelitian, maka dapat disimpulkan bahwa:

1. Jenis kesalahan siswa pada Tes Kemampuan Dasar Matematika kelas III sekolah dasar di Kabupaten Kebumen tahun 2019 adalah sebagai berikut: (1) menulis, membaca nama dan lambang bilangan (2) mengurutkan bilangan, (3) nilai tempat, (4) mengurang bilangan, (5) mengalikan 2 bilangan, (6) membagi bilangan, (7) operasi hitung campuran, (8) membandingkan, menjumlahkan, mengurangkan pecahan dengan penyebut sama., (9) perhitungan nilai uang, (10) persegi, persegi panjang, sudut, (11) pengukuran panjang, luas, berat, dan waktu.
2. Penyebab kesalahan tersebut adalah (1) kurang memahami nama dan lambang bilangan sampai dengan, (2) kurang memahami urutan pada pola bilangan, (3) kurang memahami nilai tempat ribuan, ratusan, puluhan dan satuan, (4) kurang memahami operasi pengurangan, (5) kurang memahami perkalian, (6) kurang memahami pembagian, (7) kurang memahami algoritma hitung campuran, (8) kurang memahami konsep pecahan, (9) kurang memahami konversi mata uang, (10) kurang memahami konsep luasan daerah, (11) kurang memahami pengukuran panjang, luas, dan waktu. 
3. Cara memperbaiki kesalahan siswa siswa pada Tes Kemampuan Dasar Matematika kelas III sekolah dasar di Kabupaten Kebumen tahun 2019 tersebut adalah dilakukan pembelajaran perbaikan oleh guru kelas pada masing-masing sekolah dasar, dengan fokus pembelajarannya sesuai dengan ruang lingkup materi pelajaran, jenis dan penyebab kesalahannya, yaitu (1) bilangan, (2) operasi hitung uang, (3) geometri, dan (4) pengukuran panjang, luas, dan waktu.

\section{DAFTAR PUSTAKA}

$\begin{array}{ccc}\text { Abror, A.R. } & 1993 . & \text { Psikologi } \\ \text { Pendidikan,Yoyakarta: } & \text { Tiara }\end{array}$ Wacana Yogya

Ahmadi, A., \& Supriyono, W. (1990). Psikologi Belajar. Jakarta: Rineka Cipta.

Arikunto, S. (1995). Dasar- Dasar Evaluasi Pendidikan. Jakarta: Bumi Aksara.

Babbitt, C. B., \& Miller, S. P. (1996). Using hypermedia to improve the mathematics problem-solving skills of students with learning disabilities. Journal of Learning Disabilities, 29(4), 391-401.

Block, James h. (1971). Introduction to Mastery Learning: Theory and Practice. New York: Holt, Rinehart and Winston Inc.

Burns, Robert. (1987). Models of Instructional Organization: A Casebook on Mastery Learning and Outcome-Based Education. San Francisco: Far West Lab. for Educational Research and Development.

Boon, R. (2005). Remediation of reading, spelling, and comprehension. Sydney: Harris Park.

Cimino, Anita. (1980). Mastery Learning in Your Classroom. A Handbook for an Approach to an Alternative Learning Strategy. New York: New York City Teacher Centers Consortium.
Depdiknas. (2002). Pedoman Pelaksanaan Tes Kemampuan Dasar Bagi Siswa SD Kelas 3 $S D, S D L B$, SLB Tingkat Dasar dan MI. Jakarta: Departemen Pendidikan Nasional.

Depdiknas. (2007). Tes Diagnostik. Jakarta: Depdiknas

Depdiknas. (2008). Panduan Penyelenggaraan Pembelajaran Tuntas (Mastery-Learning) Jakarta: Direktorat Jenderal Manajemen Pendidikan Dasar dan Menengah. Direktorat Pembinaan Sekolah.

Fuchs, L. S., Fuchs, D., \& Hamlett, C. L. (1994). Strengthening the connection between assessment and instructional planning with expert systems. Exceptional Children, 61(2), 138-146.

Fuchs, Lynn S. (1995). Connecting Performance Assessment to Instruction: A Comparison of Behavioral Assessment, Mastery Learning, Curriculum-Based Measurement, and Performance Assessment. ERIC Digest E530. Available online: http://www.ed.gov/databases/ER IC Digests/ed381984. html.

Hastuti, S. (2000). Pengajaran Remedial. Yogyakarta: PT Mitra Gama Widya.

Herholdt. R., \& Sapire. I. (2014). An error analysis in the early grades mathematics: $A$ learning 
opportunity. South African Journal of Childhood Education, 4, 42-60.

Howell, K. W., Fox, S. L., \& Morehead, M. K. (1993). Curriculum-based evaluation: Teaching and decision-making (2nd ed.). Pacific Grove, CA: Brooks/Cole.

Hudson, P. \& Miller, S. (2006). Designing and Implementing Mathematics Instruction for Students with Diverse Learning Need. Boston: Allyn \& Bacon.

Joyce, B. dan Well, M. (1986). Models of Teaching. Englewood, N.J, Prentice-Hall.

McGuire, P. 2013. Using online error analysis items to support preservice teachers' pedagogical content knowledge in mathematics. Retrieved from http://www.citejournal.org/vol13/i ss $3 /$ mathematics/article1.cfm

Mukhtar dan Rusmini, (2005). Pengajaran Remedial. Jakarta: Nimas Multima.

Mukminan, (2004). Pedoman Khusus Pembelajaran Tuntas. Jakarta: Depdiknas.

Mulyasa. (2004). Implementasi Kurikulum 2004 Panduan Belajar KBK. Bandung: Remaja Rosdakarya

Olivier, A. (1996). Handling pupils' misconceptions. Pythagoras, 21,10-19

Peraturan Menteri Pendidikan Nasional No 6 Tahun 2007 tentang Pelaksanaan Standar Isi dan Standar Kompetensi Lulusan untuk Satuan Pendidikan Dasar dan Menengah. Jakarta: Mendiknas

Permendikbud No. 66 Tahun 2013 tentang Standar Penilaian Pendidikan. Jakarta: Kemendikbud.
Rienties B, Martin Rehm, and Joost Dijkstra (2005). Remedial online teaching in theory and practice. Netherlands: Maastricht University Publ.

Salvia, J., \& Ysseldyke, J. E. (2004). Assessment (9th ed.). Boston: Houghton Mifflin Company.

Stein, M., Silber, J., \& Carnine, D. (1997). Designing effective mathematics instructions: $A$ direct instruction approach (3rd. ed.) Upper Saddle River, NJ: Prentice-Hall.

Sukardi. (2010). Evaluasi Pendidikan Prinsip dan Operasionalnya. Jakarta: Bumi Aksara.

Syamsuddin, A.M., 2005. Psikologi Kependidikan Perangkat Sistem Pengajaran Modul, Bandung: Remaja Rosdakarya.

Tim Penyusun KTSP. (2007). Kurikulum Tingkat Satuan Pendidikan (KTSP) SD Negeri 2 Seboro. Kebumen: SD Negeri 2 Seboro.

Wijaya, C. (2010). Pendidikan Remedial Sarana Pengembangan Mutu Sumber Daya Manusia. Bandung: PT Remaja Rosdakarya.

Woodward, J., Baxter, J., \& Robinson, R. (1999). Rules and reasons: Decimal instruction for academically low achieving students. Learning Disabilities Research \& Practice, 14(1), 1524.

Yamin, Martinis. (2006). Profesionalisasi Guru dan Implementasi Kurikulum Berbasis Kompetensi. Jakarta: Gaung Persada Press.

Yang, C. W., Sherman, H., \& Murdick, N. (2011). Error Pattern Analysis of Elementary School-Aged Students with Limited English Proficiency. Investigations in 
Mathematics Learning, 4(1), 50- Yetkin, E. (2003). Students' difficulties

67.

doi: $10.1080 / 24727466.2011 .117$ 90309. in learning elementary mathematics. Retrieved from http://www.tpdweb.umi.com/tpwe b 